\title{
Presentación de La mirada anterior. Poder visionario e imaginación en India antigua
}

El 17 de agosto de 2017 se llevó a cabo la presentación del libro $\mathrm{La}$ mirada anterior. Poder visionario e imaginación en India antigua ${ }^{1}$ en el Instituto de Investigaciones Filológicas. Junto con el autor -Óscar Figueroa (CRIM, UNAM) - , Benjamín Preciado (CEAA, Colmex) y una audiencia generosa y participativa, tuve la oportunidad de comentar algunos aspectos de la obra que me parecieron destacables.

Normalmente el curso de la investigación en indología es: algún estudioso en las lenguas representativas de los estudios indológicos - inglés, francés o alemán - presenta una investigación original y después los hispanoablantes interesados podemos elegir entre dos opciones: leerla en la lengua original o esperar - muchas veces de manera indefinida - a que se haga la traducción al español. Expresado de esta forma quizás el asunto no parezca grave, pues es labor del investigador estar actualizado y tener las herramientas para hacerlo (e. g. el conocimiento de las lenguas); sin embargo, esto puede convertirse en un obstáculo insalvable cuando damos clases y deseamos que los alumnos lean, no ya las fuentes primarias (en sánscrito), sino incluso las secundarias. Este es, pues, el círculo vicioso en el que por muchos años la investigación en español sobre indología se ha estancado. Si bien el interés por la India clásica es frecuente, la oportunidad de profundizar en su estudio exige demasiados requisitos previos.

1 Óscar Figueroa (2017). La mirada anterior. Poder visionario e imaginación en India antigua. México, Universidad Nacional Autónoma de México/Centro Regional de Investigaciones Multidisciplinarias/Instituto de Investigaciones Filológicas. 
El trabajo de Óscar Figueroa, no sólo en esta obra - pero sí particularmente en ella - me entusiasma mucho porque rompe con tal círculo vicioso. Este libro, que muchos estudiosos de otros lugares querrán y deberán leer, se encuentra en español y eso cambia de manera radical el statu quo: lo que allí se presenta tendrá que traducirse - tarde o temprano - al inglés, al francés, al alemán. Sin ninguna duda esto marca el inicio de un periodo prometedor para los estudios indológicos en nuestra lengua.

La mirada anterior tiene varias virtudes y bondades. Entre las virtudes, que son las que hacen al libro relevante para quienes se dedican al estudio de la India (digamos para el público académico), mencionaré sólo algunas:

- Presenta una gran cantidad de autores y obras sánscritas en un contexto significativo, es decir, no solamente a manera de manual descriptivo.

- Muchas de las citas textuales provienen de obras que nunca han sido traducidas al español, así que -incluso como pura antología - se trata de un documento de gran valor tanto para el ámbito didáctico como para el de la investigación.

- La bibliografía es profusa y especializada, un verdadero instrumento de rastreo para quienes deseen jalar alguno de los hilos que Figueroa pone a la vista y que sirven como invitación para futuras investigaciones.

Ahora, entre las bondades, que son las que permiten que el público general se acerque al tema y no se sienta rechazado por un lenguaje demasiado técnico, el tratamiento árido de la materia de estudio o simplemente la impresión de que el libro está dirigido para alguien más, mencionaré un par de aspectos:

- El autor tiene una particular facilidad para explicar los conceptos complejos como si no lo fueran; de esa forma nos ayuda a entrar en terrenos de difícil acceso casi sin darnos cuenta.

- Por ello, puedo imaginar a un lector que por primera vez se acerque al estudio de la India a través de este texto, sintiéndose profundamente enganchado: el estilo es claro, la estructura amigable y el lenguaje muchas veces poético. 
Así, el libro que Figueroa presenta es de interés no sólo para estudiosos de la India, sino porque abre una serie de puertas (quizá William Blake diría "the doors of perception") hacia el universo mental de una cultura particularmente consciente del poder de las imágenes. Visiones e imaginaciones, en su sentido más trascendente, son los temas alrededor de los cuales gira esta obra y a través de los cuales se analizan tres figuras fundamentales para la cultura sánscrita: el sacerdote inspirado ( $r s i)$, el poeta (kavi) y el practicante de yoga (yogi). Al lado de estos tres personajes aparecen también sus contrapartes: los filósofos, grandes escépticos de la imaginación y de sus peligrosos poderes. En fin, el libro es un recorrido por la historia de la imaginación en la India antigua, donde adeptos, disidentes e innovadores son presentados en su adecuado entorno cultural, haciendo referencia a las fuentes directas.

Wendy J. Phillips Rodríguez 